\title{
Business Strategy and Overvaluation: Evidence from Korea
}

\author{
Sangkwon CHA ${ }^{1}$, Sunpil HWANG ${ }^{2}$, Yibae KIM ${ }^{3}$ \\ Received: June 10, 2019 Revised: July 16, 2019 Accepted: September 24, 2019
}

\begin{abstract}
The purpose of this study is to test the effect of business strategy on valuation error. Business strategy includes managerial decision making and managerial tendency. In previous research, there is a negative relationship between business strategy and accounting quality. In this study, we try to confirm whether strategy tendencies affected valuation errors. In order to confirm empirically between business strategy and overvaluation, we use 8,117 firms that between 2006 and 2017 and listed in KSE and KOSDAQ. We calculated business strategy which is introduced by Bentley, Omer, and Sharp (2013). We also used the overvaluation method introduced in Rhodes-Kropf, Robinson, and Viswanathan (2005). The results show that the more the leading business strategy is, the greater the value error becomes. In the case of dividing into leading and defensive companies, the lead firms showed a significant positive correlation with the valuation errors, while the defensive firms showed the negative relationship with overvaluation. This study examined the business strategy and the overvaluation. we confirmed whether the management strategy deepens the evaluation error caused by the firm characteristics. The results are meaningful that we extended the study on the quality of financial reporting of leading strategic firms.
\end{abstract}

Keywords : Business Strategy, Overvaluation, Firm Specific Error, Firm Value

JEL Classification Code : B26, D52, M41

\section{Introduction}

The purpose of this study is to test the effect of business strategy on valuation error. Valuation error is the difference between firm's market value and its intrinsic value (RhodesKropf, Robinson, \& Viswanathan, 2005). Market value and intrinsic value are affected by various factors. For example, when manager's do earnings management or conservative accounting method, the quality of accounting information could be low. In other words, investors cannot properly use to valuation. Even though the stock price reflects accounting

1 First Author and Corresponding Author, Ph.D. Candidate, Graduate School of Hanyang University, Seoul, Korea. Email: sangkwon@hanyang.ac.kr

2 Co-Author, Ph.D. Candidate, Graduate School of Hongik University, Seoul, Korea.

Email: sunpilwow@naver.com

3 Co-Author, Associate Professor, The Department of Accounting, Duksung Women's University, Seoul, Korea.

Email: kyibae@daum.net

(c) Copyright: Korean Distribution Science Association (KODISA)

This is an Open Access article distributed under the terms of the Creative Commons Attribution Non-Commercial License (http://Creativecommons.org/licenses/by-nc/4.0/) which permits unrestricted noncommercial use, distribution, and reproduction in any medium, provided the original work is properly cited. information, the market is not efficient. In this case, Investors do not properly reflect earnings information such as accruals and cash flow. In previous studies that managerial earnings adjustment seemed to intensify the valuation error phenomenon. This is what we called functional fixation.

In the related research, the business strategies were divided into two major categories. One is a leading business strategy and the other is a defensive business strategy. According to Miles and Snow (1986), leading business strategies are aggressive in market penetration, product development and investment, and manager's tendency to pursue risk, while defensive management strategies focus on cost reduction based on learning effect and focus on current business. And that this shows a tendency to avoid risk (Gupta, Khurana, \& Pereira, 2008, Kao, Wu, \& Yang, 2009).

Therefore, we believe that there is a certain relationship between the management strategy and valuation errors. We examine the relationship between business strategy and valuation errors in KSE and KOSDAQ market from 2003 to 2017. The result of the empirical analysis is that the more the leading business strategy is implemented, the greater the error of valuation. 
This study is a follow-up study of the relationship between business strategy and accounting information that has been actively conducted recently, and it has additional contribution in that it is the first study that examines the effect of business strategy on valuation error. The previous study simply examined the relationship between business strategy and the quality of accounting information. However, this study confirms the effect of management strategy on accounting information utilization.

Our study is composed as follows. In Chapter 2, we review previous studies and set up research hypotheses based on them. Chapter 3 describes the research methodology for verifying hypotheses, Chapter 4 presents the results of empirical analysis, and Chapter 5 describes conclusions, limitations, and contributions in sequence.

\section{Literature Review}

Business strategy is a concept that is difficult to materialize in terms of various interpretations depending on the scholar and the point of view. In general, business strategy is interpreted as a structured plan designed to enable companies to continuously create competitive advantage in order to achieve their desired objectives. When managers' try to establish a strategy for continuously creating a competitive advantage, the competence of the company and the propensity of the manager are inevitably included. Managers devise action plans that can materialize to implement management philosophy and vision. To analyze the external and internal situation in the same way as SWOT in order to grasp the competence of the company, managers examine its superiority source that creates value-added internally through the value chain. Specific management strategies will be divided into firm-wide strategies, business unit strategies, and functional strategies.

According to the study by Miles and Snow (1986), companies are divided into two groups in accordance to their strategies: the leading tendency and the defensive tendency. Leading companies compete based on diverse and rapidly changing products and innovations, and companies that follow defensive strategies define strategies that compete with narrower, more stable products and production efficiency.

Theoretically, it points out that leading companies have higher information asymmetry than defensive firms because they have more certain characteristics such as $R \& D$ and growth opportunities (Aboody \& Lev 2000; Barth, Beaver, \& Landsman, 2001).

However, empirical studies do not provide consistent results. Bentley-Goode, Newton, and Thompson (2017) has suggested that information asymmetry in leading firms is rather low. In their study, leading firms with high R\&D and growth opportunities could use voluntary disclosures and press releases to lower information asymmetries.

Similar research has shown that leading firms rely on external funds for relatively high levels of R\&D spending and growth (Hambrick, 1983). There is research that managers in leading firms have high voluntary disclosure frequency to lower information asymmetry (Coller \& Yohn, 1997). In other words, the relationship between business strategy and accounting quality conflicts with the theoretical and empirical logic.

Nonetheless, many previous empirical studies seem to support the existence of information asymmetry of leading firms. Leading firms have a risk-taking tendency in decision making to take advantage of positions (Miles \& Snow, 1986).

In summary, leading firms have a greater information asymmetry, more financial reporting intervention, and aggressive accounting policies and tax avoidance tendencies, compared to relatively defensive firms (Higgins, Omer, \& Phillips, 2015; Chen, Eshleman, \& Soileau, 2016; Habib \& Hasan, 2017). The following table is summary of prior studies.

Table 1: Prospector Tendency in Business Strategy Researches

\begin{tabular}{|l|l|}
\hline researches & prospector \\
\hline Bentley et al.(2013) & $\begin{array}{l}\text { prospector showed that financial } \\
\text { reporting irregularities are frequent. }\end{array}$ \\
\hline $\begin{array}{l}\text { Bently-Goode et } \\
\text { al.(2017) }\end{array}$ & $\begin{array}{l}\text { prospector showed that Information } \\
\text { asymmetry is low. }\end{array}$ \\
\hline Higgins et al.(2015) & $\begin{array}{l}\text { prospector showed that tax avoidance } \\
\text { is high. }\end{array}$ \\
\hline Chen et al.(2016) & $\begin{array}{l}\text { prospector has more received 'going } \\
\text { concern' opinion. }\end{array}$ \\
\hline $\begin{array}{l}\text { Habib and } \\
\text { Hasan(2017) }\end{array}$ & prospector prone to crash risk. \\
\hline Houqe et al.(2015) & $\begin{array}{l}\text { prospector showed more conservative } \\
\text { accounting. }\end{array}$ \\
\hline
\end{tabular}

Accounting information, on the other hand, could be maximizes its usefulness by playing a role of reducing information asymmetry of companies and investors. There are a variety of tools available to investors in calculating firm value, but valuation tools are more likely to be used when there is a high probability of appropriate transition to the present value of a firm's future cash flows (Hertzel \& $\mathrm{Li}$, 2010).

Especially, Rhodes-Kropf, Robinson, and Viswanathan (2005) used MTB ratio to find improper valued stock. It can be argued that corporate attribute errors can be a cause of valuation errors by dividing them into firm characteristics, time-series, and growth opportunities.

Valuation errors refer to the difference between market value and intrinsic value. There is still a variety of attempts but limited consensus on how to measure intrinsic value, that is, how to measure firm value. Nevertheless, some attempts have been made to find errors in corporate valuation using the most commonly used so-called M/B ratio. The reason for looking for a valuation error is for an appropriate valuation, but the valuation error phenomenon itself can act as an agency cost (Jensen, 2005). According to 
a study by Jensen (2005), managers claimed to be able to communicate with investors using overvalued stocks. For example, earnings management can be used to justify overvalued stocks (Chi \& Gupta, 2009). In this case, the manager may have intentional financial reporting intervention. This can lead to errors in valuation.

There are some studies examining the relationship between the quality of financial reporting and the error of valuation, or examining the effect of managerial decision making (Sawicki \& Shrestha, 2012). However, there has been little research on the relationship between management strategy and valuation. Still, there is no guarantee that the management strategy will be accompanied by the personal benefit of the manager. This study extends the previous research by looking at valuation errors without a consistent conclusion about leading information asymmetry and earnings quality (Houqe, Kerr, \& Monem, 2015; Higgins, Omer, \& Phillips, 2015) In particular, we hypothesized that the business strategy had an effect on the characteristics of the firm.

H1: There is a certain relationship between business strategy and valuation error.

\section{Research Design}

\subsection{Research Model}

In order to test the hypothesis of this study, we established the below model. In the multiple regression analysis, we conducted two-way clustering of firm and year.

If the value of the business strategy (BS), which is a variable of interest in this study, shows a positive value, it means that the leading tendency increases firm valuation error. If the negative value means that the error of valuation is reduced.

In addition, additional analysis was conducted with the inclination of leading variables by inclusion of two indicating variables in the variables of interest. In this case, if the value of PRO has a significant positive value, it means that the value evaluation error is bigger in the leading tendency firm. If DEF has a negative value, the value evaluation error decreases in the defensive propensity.

$$
\begin{aligned}
F S E_{i, t}=\beta_{0}+\beta_{1} B S & (P R O \text { and } D E F)_{i, t}+\beta_{2} \operatorname{SIZE}_{i, t}+\beta_{3} L_{L V} V_{i, t} \\
& +\beta_{4} \operatorname{ROA}_{i, t}+\beta_{5} B A_{i, t}+\beta_{6} \operatorname{GRW}_{i, t} \\
& +\beta_{7} D A C C_{i, t}+\beta_{8} B I G 4_{i, t}+\beta_{9} \operatorname{LOSS}_{i, t} \\
& +\Sigma \mathrm{YEAR}+\Sigma \mathrm{SIC}+\varepsilon_{i, t}
\end{aligned}
$$

where

$$
\begin{array}{ll}
\text { FSE } & \text { firm specific error } \\
\text { BS } & \text { business strategy score } \\
\text { PRO } & 1 \text { if BS is more than } 24 \text { points, } 0 \text { if } \\
& \text { not } \\
\text { DEF } & 1 \text { if BS is less than } 13 \text { points, } 0 \text { if }
\end{array}
$$

$\begin{array}{ll} & \text { not } \\ \text { SIZE } & \log \text { (asset) } \\ \text { LEV } & \text { total debt/total asset } \\ \text { ROA } & \text { net income/total asset } \\ \text { BETA } & \text { systematic risk } \\ \text { GRW } & \text { Sales growth } \\ \text { DACC } & \text { discretionary accruals } \\ \text { BIG4 } & \text { auditor size } \\ \text { LOSS } & \text { indicator variable for loss firm } \\ \text { YEAR } & \text { dummy variable by year } \\ \text { SIC } & \text { dummy variable by industry }\end{array}$

\subsection{Business Strategy}

Bentley, Omer, and Sharp (2013), based on the theory of Miles and Snow (1986), measured the firm's propensity as a leading and defensive case based on quantitative indicators.

The leading firm is a strategy to lead the market based on $R \& D$ and aggressive investment. In defensive firm, it shows a risk-avoiding tendency and focuses on steady profit creation.

In the study of Bentley, Omer, and Sharp (2013), the six factors of R\&D, operational efficiency, growth, marketing, organizational stability, and capital intensity were measured.

The $R \& D$ ratio to sales ratio is defined as the $R \& D$ cost divided by the sales amount, and the arithmetic mean value of the last five years is defined as the R\&D intensity.

Second, in the case of the ratio of employees to sales, the arithmetic average of the number of employees by year divided by sales for each year is defined as employee concentration.

Third growth rate was defined as the average of five years, as well as the previous measures of sales growth rate.

Fourth measure is the arithmetic mean of five years, the same as the previous measurement method.

Fifth, the standard deviation of the number of employees in the five years is taken as the measure.

Sixth, the weight of the net tangible assets is measured as the arithmetic average of five years, where net tangible assets exclude land and assets under construction from total tangible assets.

These six factors are scored from 1 to 5 points per industry-year, and a total score of 30 points is obtained. However, the proportion of net tangible assets to total assets is defensive as the ratio is higher, and the score is calculated in the reverse order as the lower is the leading characteristic.

The higher the score means the more leading tendency. The lower means the defensive tendency. For the analysis of indicator variables, we classified a prospector for a business strategy index of 24 points or more and a defender for a score of 12 or less according to the study method of Bentley, Omer, and Sharp (2013). To 13 points were classified as analytical tendency (analyzer). 


\subsection{Overvaluation}

Overvaluation is estimated using the methodology of Rhodes-Kropf, Robinson, and Viswanathan (2005). According to their study, market-to-book ratio is divided into three categories: firm-specific error, time-series error, long-term value. This measurement is useful in that the growth can be separated from the valuation error compared to simply measuring the market value to the book value ratio. Market to book value can be described as the equation (1). Where $\mathrm{M}$ is the market value, $\mathrm{V}$ is the intrinsic value, and $\mathrm{B}$ is the book value. $\mathrm{M} / \mathrm{V}$ is a valuation error, and $\mathrm{V} / \mathrm{B}$ is a growth opportunity.

$$
\mathrm{M} / \mathrm{B}=M / V \times V / B
$$

Taking a $\log$ on both sides is equivalent to the below equation.

$$
(\mathrm{m}-\mathrm{b})=(m-v)+(v-b)
$$

At time $t$, the firm could have two errors. if we rewrite down the equation including growth opportunity, it would be the below equation.

$$
\begin{array}{r}
m_{i, t}-b_{i, t}=m_{i, t}-v\left(\theta_{i, t} ; \alpha_{j, t}\right)+v\left(\theta_{i, t} ; \alpha_{j, t}\right) \\
-\left(\theta_{i, t} ; \alpha_{j}\right)+v\left(\theta_{i, t} ; \alpha_{j}\right)-b_{i, t}
\end{array}
$$

$m_{i, t}-v\left(\theta_{i, t} ; \alpha_{j, t}\right)$ is the firm specific error, which is between fundamental value and market value.

$v\left(\theta_{i, t} ; \alpha_{j, t}\right)-\left(\theta_{i, t} ; \alpha_{j}\right)$ is time-series valuation error which is between fundamental value and long-run value.

$v\left(\theta_{i, t} ; \alpha_{j}\right)-b_{i, t}$ is between current book value and long-run value, which is the firm's growth opportunity.

As mentioned above, $m_{i, t}$ is market value, $b_{i, t}$ is book value, $v\left(\theta_{i, t} ;\right)$ is linear function of accounting information. $\alpha$ is a vector, the conditional accounting multiplier.

In order to calculate $v\left(\theta_{i, t} ; \alpha_{j, t}\right)$, we calculate the valuation model using the book value (b), net income (NI), debt ratio (LEV) and loss dummy (LOSS). In the following equations, + indicates an absolute value.

$$
\begin{gathered}
m_{i, t}=\alpha_{0, j, t}+\alpha_{1, j, t} b_{i, t}+\alpha_{2, j, t} N I_{i, t}^{+}+\alpha_{3, j, t} L O S S \times N I_{i, t}^{+} \\
+\alpha_{4, j, t} L E V_{i, t}+\varepsilon_{i, t}
\end{gathered}
$$

\subsection{Control Variable}

The control variables are firm size, debt ratio, profitability, systematic risk, growth rate, earnings quality, auditor size, loss dummy variable and industry and year dummy variables.

Firm size(SIZE) is the natural log of total assets. and it has the effect of controlling the factors related to the characteristics of the company which are not considered in this study. The debt ratio (LEV) is the total debt divided by the total assets. Profitability(ROA) is calculated by dividing net income by total assets. Systematic risk(BETA) indicates the risk that investors are not dispersed even when using individual stock portfolios. The relationship between systemic risk and valuation error is predicted positively.

Growth(GRW) was calculated based on sales. A firm with a high growth rate is expected to have a positive correlation with the valuation error based on previous research that high earnings adjustment and information asymmetry are high. In order to consider the impact of the quality of accounting information, discretionary accruals were included in the control variables. Discretionary accruals are the method of Dechow, Sloan, and Sweeney (1995).

$$
\begin{aligned}
\frac{\text { TACC }_{i, t}}{A_{i, t-1}}=\beta_{0}+\beta_{1} & \frac{1}{A_{i, t-1}}+\frac{\Delta R E V-\Delta \text { REC }_{i, t}}{A_{i, t-1}}+\frac{P P E}{A_{i, t-1}} \\
& +\beta_{4} \text { ROA }_{i, t}
\end{aligned}
$$

In the above equation, regression analysis is conducted for each industry-year, indicating that the estimated residuals indicate the discretionary accruals of the individual firms and the higher the level of discretionary accruals, the more the manager increases the reporting earnings (Dechow, Sloan, \& Sweeney, 1995). TACC is total accruals, A is total asset, REV is total sales of the firm, REC is accounting receivable, PPE is total tangible asset except for land and under construction, and ROA is net income divided by total asset. In estimating the discretionary accruals, the industry uses the Korean Standard Industrial Classification subdivision, and the size of industry - year sample is more than 20. The results of this study suggest that the discretionary accruals are positive (Chi \& Gupta, 2009; Jung \& Park, 2016; Lee \& Lee, 2018).

BIG4 was included as a control variable to consider the effect of large accounting firm on the relationship between business strategy and valuation error. The large accounting firm is defined as PwC-Samil, KMPG-Samjung, E\&YHanyong, and Delloit-Anjin, if it is since 2006, and 0 otherwise (Chae \& Ryu, 2019).

And other indicators of loss(LOSS), industry(SIC), and year(YEAR). Indicators for industry were based on the Korean Standard Industrial Classification.

\subsection{Sample Selection}

In order to verify the hypothesis, we set the verification period from 2006 to 2017 for the securities market and the KOSDAQ market, and extracted data from 2000 to 2017 in the KISVALUE database of NICE valuation information. In this case, the financial industry was excluded from the Korean Standard Industrial Classification and it was excluded from the sample when the financial data required by the operational definition of the study cannot be 
calculated. For example, in the case of business strategy, the financial data of the last five years must exist continuously. In the case of the KSE market, there are 3,073 firms in the market and 5,104 firms in the KOSDAQ market. The sample of this study showed that the sample of the KOSDAQ market was larger.

\section{Empirical result}

\subsection{Descriptive statistics}

The descriptive statistics of the variables used in this study are shown in Table 2. First, the mean value of the FSE is -0.026 , which indicates that the average value of the entire sample is underestimated. For the PROSPECTOR, the average was overestimated to 0.171 , while the defensive tendency was -0.056 , which was lower than zero. In the case of BS, the overall average was 18.625 , with 23.954 in the case of leading tendency, and 17.815 in case of defensive tendency.

On the other hand, the leading tendency showed higher growth rate, higher discretionary accrual and higher loss ratio than the defensive tendency, and the debt ratio and whether the auditor was a large accounting corporation was higher than the defensive tendency.

Table 2: descriptive statistics

\begin{tabular}{|c|c|c|c|c|c|c|c|}
\hline Variable & Mean & S.D. & Min & $\mathbf{0 . 2 5}$ & Mdn. & $\mathbf{0 . 7 5}$ & Max \\
\hline FSE & -0.026 & 0.674 & -1.109 & -0.378 & -0.176 & 0.101 & 3.477 \\
\hline BS & 18.625 & 3.369 & 8 & 16 & 19 & 21 \\
\hline SIZE & 25.635 & 1.207 & 20.991 & 24.839 & 25.424 & 26.212 & 31.809 \\
\hline LEV & 0.424 & 0.193 & 0.039 & 0.27 & 0.426 & 0.563 & 0.933 \\
\hline ROA & 0.014 & 0.105 & -0.55 & -0.002 & 0.029 & 0.064 & 0.282 \\
\hline GRW & 0.105 & 0.383 & -0.68 & -0.064 & 0.054 & 0.186 & 2.73 \\
\hline DACC & 0.002 & 0.08 & -0.253 & -0.043 & -0.001 & 0.041 & 0.304 \\
\hline BETA & 0.009 & 0.004 & 0.001 & 0.006 & 0.009 & 0.011 & 0.023 \\
\hline BIG4 & 0.5 & 0.5 & 0 & 0 & 0 & 1 & 1 \\
\hline LOSS & 0.254 & 0.435 & 0 & 0 & 0 & 1 \\
\hline
\end{tabular}

\subsection{Correlation}

Table 3 shows the Pearson correlation analysis of the variables used in this study. The relationship between the BS and the FSE was showed a positive relationship. This indicates that the more the tendency to show the leading tendency, the more the error of valuation

On the other hand, the relationship between the control variable and the valuation error shows a positive (+) relationship with the debt ratio (LEV), growth rate (GRW), discretionary accruals (DACC), systematic risk (BETA) Respectively. In other words, the higher the debt ratio, the greater the growth rate, the higher the level of discretionary accruals, the higher the systematic risk, the greater the error in valuation of loss firms. On the other hand, there is a significant negative relationship between analytic tendency (ANA), size of company (SIZE), profitability (ROA) and large accounting corporation (BIG4).

However, since this relationship is the result of univariate analysis, it is examined through multiple regression analysis whether the relationship between the business strategy of interest and the valuation error is maintained even after controlling certain variables. Also, the high correlation between the variables in the correlation analysis was confirmed by the dispersion expansion index in the multiple regression analysis, and the dispersion expansion index was not more than 5 .

\subsection{Regression}

Multiple regression analysis was conducted to verify the hypothesis of this study. The regression coefficient and $t$ value are not reported separately. The $F$ value, which means fitness of the model, was 37.961 for model 1 and 33,761 for model 2, and both models showed a significant value at $1 \%$ level. In the case of adj. $\mathrm{R}^{2}$, meaningful explanatory power of the model, 0.160 and 0.153 , respectively.

The analysis of the results of the variables of interest shows that the value of the business strategy (BS) of the model (1), which is a continuous variable, shows a positive value. It implies the company's risk-seeking propensity can be seen as a factor that deepens overvaluation. In order to confirm the results of the model (1), as shown by the indicator variables like the model (2), when the leading tendency is shown, there is a positive relationship between the value evaluation error and $1 \%$. This suggests that the more aggressive the tendency is, the more the value error increases.

These results show that aggressive investment and its high information asymmetry can be a cause of deepening the valuation errors (Dong, Hirshleifer, \& Teoh, 2012). In case of defensive strategy, it is a strategy to compete with narrower and more stable product and production efficiency, this means that errors in valuation in terms of the characteristics of the company in terms of stance can be mitigated. 
Table 3: Correlation

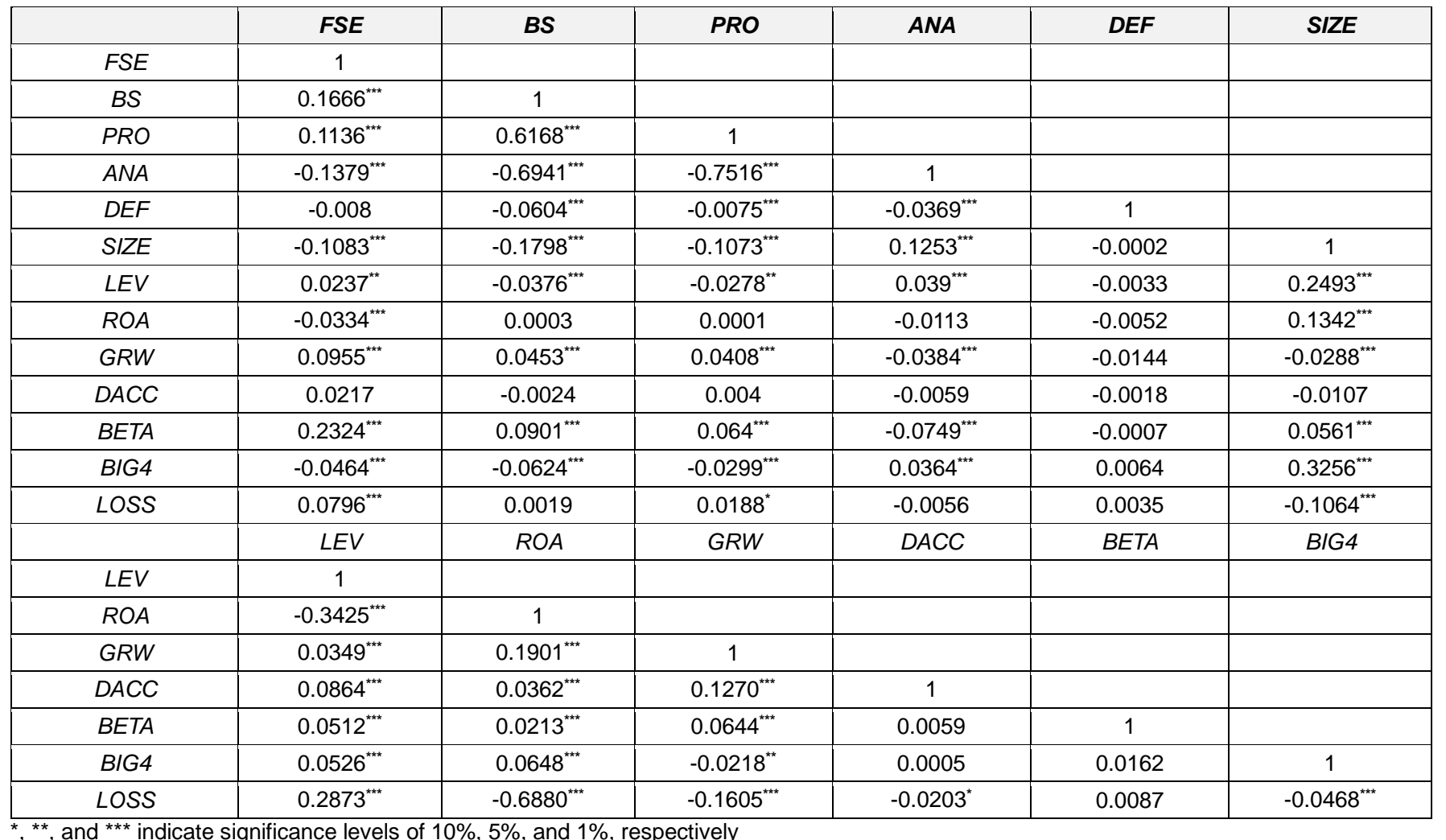

Table 4: Regression Result

\begin{tabular}{|c|c|c|c|c|}
\hline intercept & 0.208 & -0.38 & $0.949^{*}$ & -1.71 \\
\hline BS & $0.024^{* * *}$ & 5.93 & & \\
\hline PRO & & & $0.152^{\star \star \star}$ & 4.71 \\
\hline DEF & & & $-0.120^{\star}$ & $(-1.88)$ \\
\hline SIZE & $-0.047^{\star \star \star}$ & $(-2.97)$ & $-0.059^{\star \star \star}$ & $(-3.62)$ \\
\hline LEV & $0.225^{\text {t*t* }}$ & 3.14 & $0.240^{\star \star \star}$ & 3.33 \\
\hline ROA & $0.294^{*}$ & 1.69 & $0.315^{\star}$ & 1.85 \\
\hline GRW & $0.122^{* * *}$ & 3.08 & $0.126^{\star \star \star *}$ & 3.24 \\
\hline CFO & $-0.239^{* *}$ & $(-2.36)$ & $-0.262^{\star \star}$ & $(-2.53)$ \\
\hline DACC & -0.048 & $(-0.52)$ & -0.075 & $(-0.83)$ \\
\hline BETA & $34.068^{\star \star \star}$ & 6.66 & $35.514^{\star \star \star}$ & 7.02 \\
\hline BIG4 & 0.004 & 0.15 & 0.006 & 0.24 \\
\hline LOSS & $0.128^{* *+*}$ & 3.7 & $0.124^{* \star \star *}$ & 3.58 \\
\hline SIC & \multicolumn{2}{|c|}{ Included } & \multicolumn{2}{|c|}{ Included } \\
\hline YEAR & \multicolumn{2}{|c|}{ Included } & \multicolumn{2}{|c|}{ Included } \\
\hline adj. $R^{2}$ & \multicolumn{2}{|c|}{0.160} & \multicolumn{2}{|c|}{0.153} \\
\hline$F$ & \multicolumn{2}{|c|}{$37.961^{* * *}$} & \multicolumn{2}{|c|}{$33.761^{* *}$} \\
\hline $\mathbf{N}$ & \multicolumn{2}{|c|}{8,117} & \multicolumn{2}{|c|}{8,117} \\
\hline
\end{tabular}

\subsection{Additional test}

The main results of this study include the loss firms and the loss firms have different impacts on the valuation, so the sample excluding the loss firms should be reconstructed to confirm the results of this analysis. As a result of the analysis (table 5.), the value of BS showed a significant positive value. As the business strategy of the company shows the leading tendency, the value error increases. In the case of analysis by the indicator variables, there is a significant positive value for the leading tendency and no significant value for the defensive enterprise. The valuation of a defensive firm, centered on relatively stable production and efficiency, indicates that errors are not large. 
Table 5: Result after Excluding Loss Firms

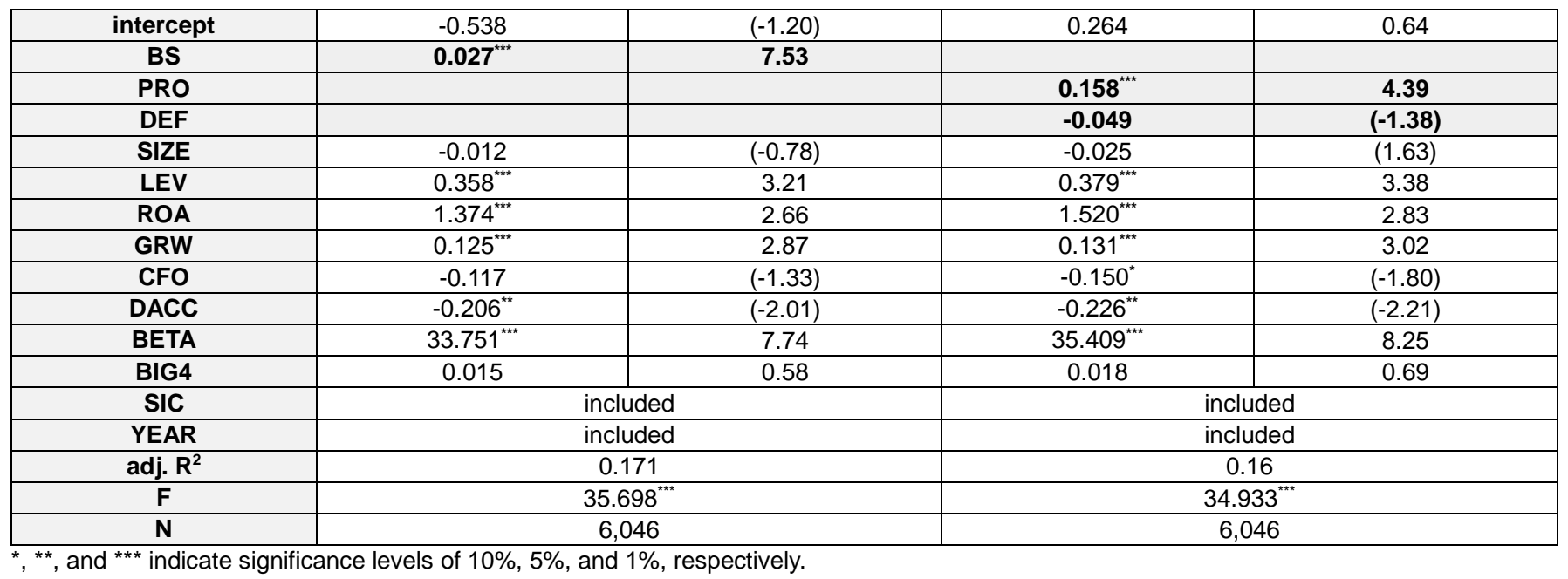

In this section, we reconfigured the business strategy index to see if it can produce the same results as the main analysis. PRO and DEF each have 7 interval values. Bentley, Omer, and Sharp (2013), the leading case and the defensive case were divided into eight sections, respectively, and analyzed. PRO2 is defined as 1 if the business strategy index belongs to 8 from 23 to 30 . Otherwise, DEF2 is defined as 1 if it belongs to 9 from 6 to 13, and 0 otherwise. In addition, PRO3 is divided into 1 if it is 18 or more and 0 otherwise.

The results of the empirical analysis show that both PRO2 and PRO3 have significant positive values.

Table 6: Result for Reclassified Business Strategy Index

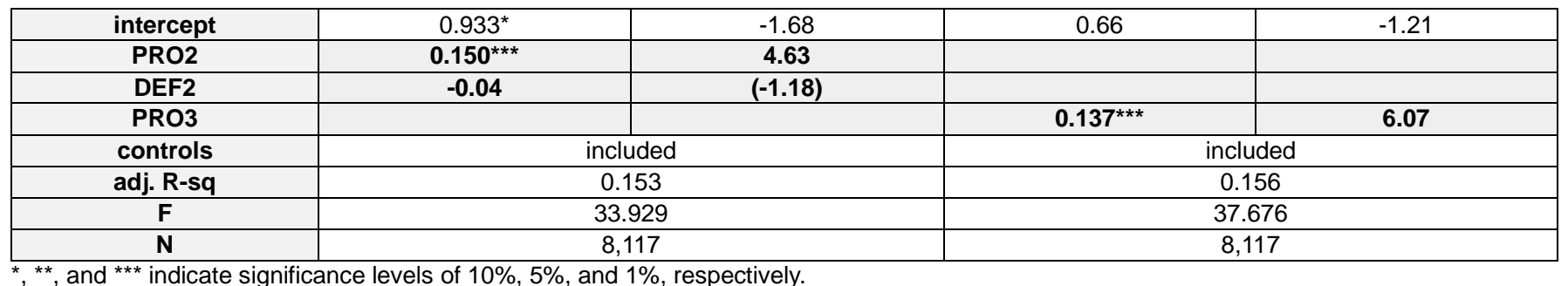

In summary, the relationship between the business strategy index and the valuation error is positive. This means that the more the leading tendency is expressed, the greater the error of valuation due to the characteristics of the company. The results of the main analysis were able to draw the same conclusions after excluding the loss firms. Even after readjusting the business strategy index, the result of the analysis shows that the same tendency of the leading tendency leads to a large value error.

Although not mentioned in the main text, we have further verified that the relationship between the leading tendency and the amount of the valuation error depends on the interaction with the large auditor. In the case of an auditor size with a large accounting firm, the relationship between the leading tendency and the amount of valuation errors (+) shows that the significance disappears.

\section{Conclusion}

The purpose of this study is to examine whether the business strategy, which is the manager's decision, affects the firm characteristic valuation error. We analyze the relationship between the business strategy and the error of valuation of the corporation, from 2006 to 2017. As a result of the empirical analysis, the more the leading tendency, the greater the value error. In the case of the leading tendency, the value error increases.

An advantage in that the measurement of business strategy and valuation error can be calculated based on accounting information, but it has the disadvantage of causing measurement errors at the same time. This implies that a company can be included in a business strategy that is different from the actual business strategy, and there are limitations to the differentiation even though a complex business strategy. Various strategies that are difficult to be dichotomized can exist.

As we mentioned, there are mixed results of the effects of leading and defensive firms on accounting information. This study has contributed to show additional empirical evidence. In particular, while prior studies tested that the impact on the quality of accounting information, this study 
examines the value of accounting information in terms of valuation.

This study suggests policy implications to financial authorities by explaining the effect of management strategy, which is the product of CEO 's decision, on the quality of accounting information as well as the influence of capital market.

\section{References}

Aboody, D., \& Lev, B. (2000). Information asymmetry, $\mathrm{R} \& \mathrm{D}$, and insider gains. The journal of Finance, 55(6), 2747-2766.

Barth, M. E., Beaver, W. H., \& Landsman, W. R. (2001). The relevance of the value relevance literature for financial accounting standard setting: Another view. Journal of Accounting and Economics, 31(1-3), 77-104.

Bentley, K. A., Omer, T. C., \& Sharp, N. Y. (2013). Business strategy, financial reporting irregularities, and audit effort. Contemporary Accounting Research, 30(2), 780-817.

Bentley-Goode, K. A., Newton, N. J., \& Thompson, A. M. (2017). Business strategy, internal control over financial reporting, and audit reporting quality. Auditing: A Journal of Practice \& Theory, 36(4), 49-69.

Chen, Y., Eshleman, J. D., \& Soileau, J. S. (2016). Business strategy and auditor reporting. Auditing: A Journal of Practice \& Theory, 36(2), 63-86.

Chi, J. D., \& Gupta, M. (2009). Overvaluation and earnings management. Journal of Banking \& Finance, 33(9), $1652-1663$.

Chae, A., \& Ryu. B. (2019). The relationship between corporate social responsibilities and financial reporting quality: Focusing on distribution \& service companies. Journal of Distribution Science, 16(10), 77-82.

Coller, M., \& Yohn, T. L. (1997). Management forecasts and information asymmetry: An examination of bid-ask spreads. Journal of Accounting Research, 35(2), 181-191.

Dong, M., Hirshleifer, D., \& Teoh, S. H. (2012). Overvalued equity and financing decisions. The Review of Financial Studies, 25(12), 3645-3683.

Dechow, P. M., Sloan, R. G., \& Sweeney, A. P. (1995). Detecting earnings management. The Accounting Review, 70(2), 193-225.
Gupta, M., Khurana, I. K., \& Pereira, R. (2008). Legal inforcement, short maturity debt, and the incentive to manage earnings. The Journal of Law and Economics, 51(4), 619-639.

Habib, A., \& Hasan, M. M. (2017). Business strategy, overvalued equities, and stock price crash risk. Research in International Business and Finance, 39(A), 389-405.

Higgins, D., Omer, T. C., \& Phillips, J. D. (2015). The influence of a firm's business strategy on its tax aggressiveness. Contemporary Accounting Research, 32(2), 674-702.

Hambrick, D. C. (1983). High profit strategies in mature capital goods industries: A contingency approach. Academy of Management Journal, 26(4), 687-707.

Hertzel, M. G., \& Li, Z. (2010). Behavioral and rational explanations of stock price performance around SEOs: Evidence from a decomposition of market-to-book ratios. Journal of Financial and Quantitative Analysis, 45(4), 935-958.

Houqe, M. N., Kerr, R., \& Monem, R. (2015). Business strategy, economic growth, and earnings quality (Working paper). Wellington, New Zealand: Victoria University of Wellington.

Jensen, M. C. (2005). Agency costs of overvalued equity. Financial Management, 34(1), 5-19.

Jung, K. S., \& Park, C, K. (2016). The effect of corporate social responsibilities on the quality of corporate reporting, Journal of Distribution Science, 14(6), 75-80.

Kao, J. L., Wu, D., \& Yang, Z. (2009). Regulations, earnings management, and post-IPO performance: The Chinese evidence. Journal of Banking \& Finance, 33(1), 63-76.

Lee, B. Y., \& Lee, S. H. (2018). A study on financial ratio and prediction of financial distress in financial markets. Journal of Distribution Science, 16(11), 21-27.

Miles, R. E., \& Snow, C. C. (1986). Organizations: New concepts for new forms. California Management Review, 28(3), 62-73.

Rhodes-Kropf, M., Robinson, D. T., \& Viswanathan, S. (2005). Valuation waves and merger activity: The empirical evidence. Journal of Financial Economics, 77(3), 561-603.

Sawicki, J., \& Shrestha, K. (2012). Overvalued equity and the accruals anomaly: Evidence from insider trades. Procedia Economics and Finance, 2(0), 91-100. 